\title{
The effects of UV light on the antimicrobial activities of cave actinomycetes
}

\author{
Devon Rule and Naowarat Cheeptham* \\ Department of Biological Sciences, Faculty of Science, Thompson Rivers University, 900 McGill Rd., Kamloops, BC, V2C 0C8, Canada
}

\begin{abstract}
The goal of this study was to determine whether actinomycetes isolated from a volcanic cave in western Canada could produce novel antimicrobial compounds against six multidrugresistant pathogens when exposed to UV light. One hundred and seventy-six actinomycete strains isolated from Helmcken Falls Cave, Wells Gray Provincial Park, BC, were screened against six pathogens using the "plug assay" in UV light and no light conditions. Of the 176 strains tested, 100 or $57 \%$ of the cave actinomycete strains had antimicrobial activities against the pathogens in 124 different instances: 35 instances when exposed to UV and no light, 30 when exposed to UV light, and 59 instances when exposed to no light. The metabolites of six actinomycete strains also lost their antimicrobial activities when exposed to UV light. While the metabolites produced by these strains have yet to be determined, exposure to lighted environments may either deactivate or enhance the antimicrobial activities of cave actinomycete strains. This study represents a confirmation that cave actinomycetes are potential sources of novel antimicrobial compounds and also is the first report of the enhancement of antimicrobial activities of some cave bacteria by exposure to UV light. Further investigation of the role of UV light with respect to activation/deactivation of antimicrobial activities of cave actinomycetes is required.
\end{abstract}

Keywords: volcanic cave; antimicrobial activity; cave actinomycetes; UV effects; multidrug resistance pathogens

Received 13 February 2013; Revised 1 May 2013; Accepted 13 May 2013

Citation: Rule D. and Cheeptham N., 2013. The effects of UV light on the antimicrobial activities of cave actinomycetes. International Journal of Speleology, 42 (2), 147-xx. Tampa, FL (USA) ISSN 0392-6672 http://dx.doi.org/10.5038/1827-806X.42.2.7

\section{INTRODUCTION}

Antibiotic resistance continues to pose a significant threat to the clinical and pharmaceutical world. Many common hospital pathogens are becoming multi-drug resistant and are unable to be treated with many -if any- of the commercially available antibiotics (Davies \& Davies, 2010). Multi-drug resistant microorganisms are a significant problem as they are a leading cause of human death worldwide (Selvameenal et al., 2009) and antibiotics are still currently the only effective way to treat infectious microbial diseases. Thus, the need for novel antimicrobial compounds is greater now than ever before. Fortunately, filamentous, Gram-positive bacteria known as the actinomycetes-particularly the Streptomyces species- produce antimicrobials in nature and have been the largest source of new antibiotic drug candidates and leading molecules to date (Genilloud et al., 2011). Out of the 22,500 secondary metabolites with antimicrobial activities that have been found in studies, 10,100 (or 45\%) have been produced by actinomycetes (Selvameenal et al., 2009). In particular, actinomycetes from less-explored habitats show exceptional promise to produce novel antimicrobial compounds (Genilloud et al., 2011). This was already anticipated by Groth et al. (1999) in a study on the Spanish caves of Altamira and Tito Bustillo. For instance, a new antimicrobialproducing actinomycete strain, Streptomyces tendae HKI 0179, was isolated from the ancient cave Grotta dei Cervi in Italy by Groth et al. (2001). Streptomyces tendae HKI 0179 produced novel forms of antimicrobials called cervimycins (Herold et al., 2005) which showed high levels of antimicrobial activities against the pathogens Bacillus subtilis, multi-drug resistant Staphylococcus aureus (MRSA), and vancomycin-resistant Enterococcus faecalis (VRE) 1528. These antimicrobials were as effective as those such as vancomycin, tetracycline, and ciprofloxacin that are currently used to treat infections caused by these organisms. A recent study by Rajput et al. also discovered several Streptomyces strains (Streptomyces prasinosporus KCA strains 3, 8, and 22, Streptomyces aurantiacus KCA6, Streptomyces 
roseus KCA13, Streptomyces longiosporoflavus KCA18, and Streptomyces luridus KCA23) isolated from the Kotsumar Cave in India that produced significant antimicrobial activities against the three drug-resistant human pathogens Pseudomonas aeruginosa, Escherichia coli, and Staphylococcus aureus (Rajput et al., 2012). Overall, these studies show that natural antimicrobial compounds produced by cave actinomycetes are strong contenders for the new antimicrobials that are needed to ease the multidrug resistance problem.

Previous studies have shown an increasing number of fungal and plant natural products that have lightmediated activities against fungi, insects, bacteria, viruses, and cells (Towers et al., 1997). A study carried out by Hudson and colleagues in 2000, for example, tested the antiviral activities of seven species of African medicinal plant extracts that were exposed to longwave UV light (UVA, which has a wavelength of 315$400 \mathrm{~nm}$ ) and fluorescent light (visible light, which has a wavelength of $185-254 \mathrm{~nm}$ ) against the type 1 herpes simplex virus (Hudson et al., 2000). The plant extracts showed the most antiviral activities against the virus when the extracts were exposed to light, particularly UVA light. Similarly, Cheeptham and Towers studied the light-mediated activities of a wide variety of Thai medicinal plant tea extracts in 2002 (Cheeptham \& Towers, 2002). They too demonstrated the remarkable ability of plant extracts to produce antimicrobial and antifungal compounds against an array of bacterial and fungal pathogens when subjected to UV light (from $5 \mathrm{~W} / \mathrm{m}^{2}$, 320-400 nm Sylvanian F20T12-BLB lamps). Thus, investigation as to whether UV light can stimulate the metabolites of cave actinomycetes to produce antimicrobial activities for a potentially wider and more specific therapeutic use would be of great benefit.

\section{MATERIALS AND METHODS}

\section{Organisms and growth conditions}

\section{Growth of the cave actinomycete strains}

One hundred and seventy-six cave actinomycete strains of over 400 strains previously isolated from Wells Gray Provincial Park in Clearwater, BC, Canada were primarily subcultured onto 25-30 mL Hickey Tresner (HT) agar plates (10 g/L dextrin, $1 \mathrm{~g} / \mathrm{L}$ yeast extract, $1 \mathrm{~g} / \mathrm{L}$ beef extract, $2 \mathrm{~g} / \mathrm{L} \mathrm{N}-\mathrm{Z}$ Amine Type A, $15 \mathrm{~g} / \mathrm{L}$ agar, $\mathrm{pH}$ 7.3) using the confluent-streak technique. The plates were incubated at $25^{\circ} \mathrm{C}$ for 7 to 10 days. For the strains that did not grow well, a "plug" of each strain was transferred -using the open end of a $20-200 \mu \mathrm{L}$ pipette tip (sterile)- from its original stock plate to a fermentation tube $(13 \times 100$ $\mathrm{mm}$ size) with six $\mathrm{mL}$ of HT broth. The tubes were then placed in a $25^{\circ} \mathrm{C}$ shaker for approximately 7 to 10 days to obtain uniform growth. Each of the isolates was confluent-streaked onto HT agar plates using sterile polyester tipped applicators (swabs) and was then incubated at $25^{\circ} \mathrm{C}$ for 7 to 10 days. These plates were then used as the origin of the plugs for the bioassay.

\section{Growth of the pathogens}

The six pathogen strains used in this project include: Mycobacterium smegmatis strain JVC1213 (MC 2155$)$, Extended Spectrum $\beta$-Lactamase (ESBL)-producing Escherichia coli strain 1841 JVC1195, Micrococcus luteus, Multi-Drug Resistant Staphylococcus aureus, Acinetobacter baumannii strain 14394, and Candida albicans (Table 1). The pathogens were provided by Dr. Julian Davies from the University of British Columbia (UBC), in Vancouver, BC and Dr. Gwen Stephens from the Department of Pathology at the Royal Inland Hospital (RIH), in Kamloops, BC.

To culture the pathogens, a loopful or bead (if taken from the $-80^{\circ} \mathrm{C}$ freezer) of each pathogen was placed into $40 \mathrm{~mL}$ of liquid broth medium that is known to encourage the growth of each strain (Table 1). The flask was then incubated at either $35^{\circ} \mathrm{C}$ or $25^{\circ} \mathrm{C}$ (for Candida albicans) on an orbital shaker at $200 \mathrm{rpm}$. Optical density readings of each pathogen at $600 \mathrm{~nm}$ wavelength were recorded and matched with the 0.5 McFarland standard for logarithmic growth. $0.5 \%$ of each pathogen was then transferred to the molten agar prepared for the bioassay as described below.

\section{Conventional Agar Plug Assay}

To screen for antimicrobial activity of the metabolites of the cave actinomycetes against the six multi-drug resistant pathogens, a series of seeded bioassay plates were prepared using the conventional agar plug assay (Murakami et al., 1986) also known as the agar plug method. Each of the six pathogens was grown separately in liquid medium as described above. Then, $0.5 \%(\mathrm{v} / \mathrm{v})(1.25 \mathrm{~mL})$ of each pathogen at log phase was added to two $250 \mathrm{~mL}$ flasks of molten nutrient agar (potato-dextrose-agar in the case of Candida albicans) which were kept warm in a $55^{\circ} \mathrm{C}$ water bath. The agar was then poured into two 25 by $25 \mathrm{~mm}$ square bioassay plates. After solidification, agar plugs of the cave actinomycete strains (these cave actinomycetes had already been cultured for 7 to 10 days prior to this step to ensure secondary metabolite production) were transferred onto each of the two identical bioassay plates in the same pattern using the open ends of sterile $20-200 \mu \mathrm{L}$ pipette tips (Fig. 1). A disk impregnated with sterile water was also added to each of the plates as a negative control, while a disk

Table 1. Six antimicrobial-resistant pathogens used in this study.

\begin{tabular}{|c|c|c|c|c|}
\hline $\begin{array}{l}\text { Drug-Resistant } \\
\text { Pathogen }\end{array}$ & $\begin{array}{l}\text { Medium } \\
\text { Used }\end{array}$ & $\begin{array}{c}\text { Gram } \\
\text { Reaction }\end{array}$ & $\begin{array}{l}\mathrm{OD}_{600} \\
\text { Values } \\
\text { at Log } \\
\text { Phase }\end{array}$ & $\begin{array}{l}\text { Approximate } \\
\text { Time Required } \\
\text { to Reach Log } \\
\text { Phase (hrs) }\end{array}$ \\
\hline $\begin{array}{c}\text { Mycobacterium } \\
\text { smegmatis strain } \\
\text { JVC1213 (MC2155) }\end{array}$ & N.E. & + & 0.7 & 82 \\
\hline $\begin{array}{c}\text { ESBL-producing } \\
\text { Escherichia coli strain } \\
1841 \mathrm{JVC} 1195\end{array}$ & L.B. & - & 0.6 & 6 \\
\hline Micrococcus luteus & N.B. & + & 0.6 & 12 \\
\hline MDR-S. aureus & L.B. & + & 0.5 & 5 \\
\hline $\begin{array}{l}\text { Acinetobacter } \\
\text { baumannii } \\
\text { strain } 14394\end{array}$ & N.B. & - & 0.6 & 12 \\
\hline Candida albicans & Y.M. & mold (yeast) & 0.7 & 24 \\
\hline
\end{tabular}

The medium that each pathogen was grown in, the pathogen's Gram reaction and optical density value $\left(O D_{600}\right)$ at log phase, and the approximate amount of time required to reach the pathogen's log phase (hrs) is also given. 
soaked with 3 or $5 \mathrm{mg}$ of 8-methoxypsoralen (8-MOP; a common substance that is light-reactive and can be used to show antimicrobial activity) in one $\mathrm{mL}$ of methanol was added to each plate as a UV indicator (or light-activated activity positive control).

Subsequently, one of the assay plates was subjected to one hour of UV light (254 nm) in the Labconco Flow Hood with its lid open, while the other plate received no UV light treatment and sat in the dark lab for an hour. Afterwards, the lid was placed back on the UV light plate and both the UV and no light plate were incubated overnight at $35^{\circ} \mathrm{C}\left(25^{\circ}\right.$ for C. albicans) in the dark lab. Any inhibitory zones and their diameters were measured and recorded after the incubation period. The positive controls for antimicrobial activity used in this study varied depending on the pathogens used in the assay plates (Table 2).

\section{RESULTS}

Of the 176 strains tested, the metabolites of $57 \%$ or 100 of the cave actinomycete strains had antimicrobial activities against the six pathogens tested in 124 different instances. In 35 instances the metabolites had antimicrobial activities in both UV and no light, in 30 instances they had antimicrobial activities in UV light, and in the remaining 59 instances they had antimicrobial activities in no light (Fig. 2, Table 3).

Notably, no single cave actinomycete isolate produced metabolites with antimicrobial activities against all six of the pathogens. Strain E9's metabolites, however, produced antimicrobial activities against all of the pathogens except for Candida albicans (Table 4). The metabolites of cave actinomycete strain 100 showed the greatest antimicrobial activities of all of the metabolites, producing a zone of inhibition 27 $\mathrm{mm}$ in diameter against Candida albicans in UV light conditions (Table 4). Conversely, E25's metabolites showed the least antimicrobial activities of all of the

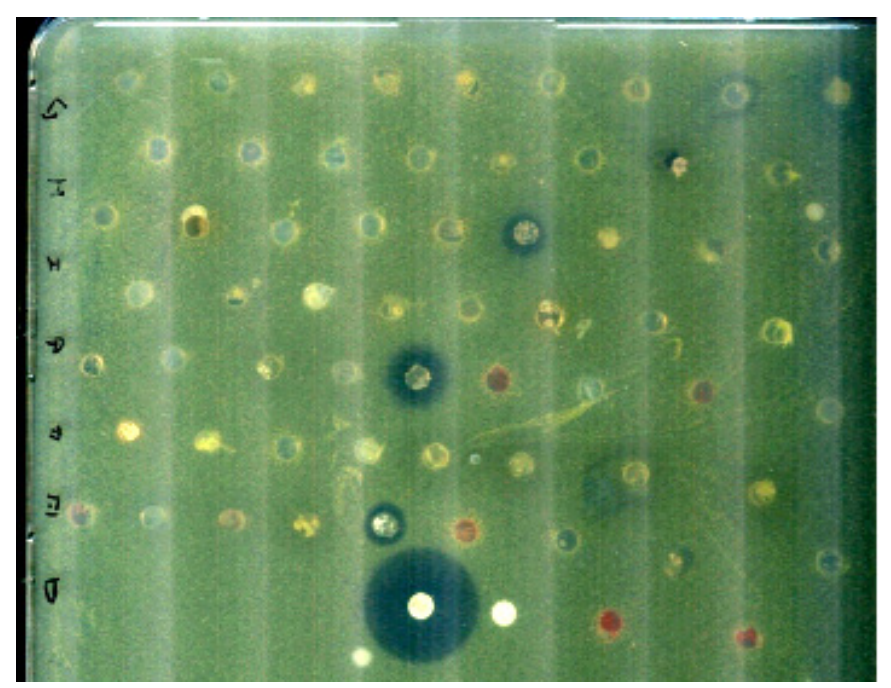

Fig. 1. An example of a seeded plate prepared using the "plug assay" to assess the antimicrobial activities of the cave actinomycete strains' metabolites against the antimicrobial-resistant pathogen Micrococcus luteus when the metabolites were exposed to UV light. The diameters of the dark, inhibitory zones that encircle the actinomycete plugs were measured to assess the antimicrobial activities of the metabolites.
Table 2. Positive controls against the six antimicrobial-resistant pathogens used in this study.

\begin{tabular}{|c|c|}
\hline Pathogen & Antibiotic Disk Used as a Positive Control \\
\hline $\begin{array}{l}\text { Mycobacterium smegmatis JVC } 1213 \\
\text { (MC2155) }\end{array}$ & $\begin{array}{l}\text { SXT (sulfamethoxazole- } 23.75 \mu \mathrm{g} \text {, and } \\
\text { trimethoprim- } 1.25 \mu \mathrm{g} \text { ) }\end{array}$ \\
\hline $\begin{array}{l}\text { ESBL-producing Escherichia coli } \\
\text { strain } 1841 \text { JVC1195 }\end{array}$ & CFP (cefoperazone- $75 \mu \mathrm{g}$ ) \\
\hline Micrococcus luteus & TET (tetracycline- $30 \mu \mathrm{g}$ ) \\
\hline MDR-S.aureus & TET (tetracycline- $30 \mu \mathrm{g}$ ) \\
\hline Acinetobacter baumannii strain 14394 & CAZ (ceftazidime $-30 \mu \mathrm{g}$ ) \\
\hline Candida albicans & N/A - antifungal (nystatin- $20 \mu \mathrm{g}$ ) \\
\hline
\end{tabular}

Table 3. The number of cave actinomycete strains' metabolites that had antimicrobial activities against the six drug-resistant pathogens in different conditions.

\begin{tabular}{ccccc}
\hline & \multicolumn{4}{c}{ Conditions } \\
\cline { 2 - 5 } Pathogen & UV light & Non-UV & Both & Total \\
\hline M. luteus & 2 & 7 & 4 & 13 \\
MDR-S. aureus & 1 & 2 & 1 & 4 \\
M. smegmatis & 11 & 28 & 10 & 49 \\
\hline ESBL- producing- E. coli & 0 & 3 & 0 & 3 \\
A. baumannii & 0 & 6 & 3 & 9 \\
\hline C. albicans & 16 & 13 & 17 & 46 \\
\hline Total & 30 & 59 & 35 & 124 \\
\hline
\end{tabular}

The pathogens that were most susceptible to the metabolites of the cave actinomycetes are shaded. The total number of metabolites that had antimicrobial activities against the pathogens in each of the different conditions is also given.

metabolites, producing not much more than a six mm zone of inhibition against ESBL-producing Escherichia coli in no light conditions. Also, it seems that Mycobacterium smegmatis and Candida albicans were the most susceptible pathogens to the antimicrobial activities of the cave actinomycetes' metabolites in this study. The metabolites of 49 cave actinomycete strains produced antimicrobial activities against Mycobacterium smegmatis, while the metabolites of 46 strains produced antimicrobial activities against Candida albicans (Table 4). The metabolites of six cave actinomycete strains lost their antimicrobial activities when they were exposed to one hour of UV light, as well (Table 5). The identification of the six cave actinomycetes by $16 \mathrm{~S}$ rRNA sequencing is shown in Table 6.

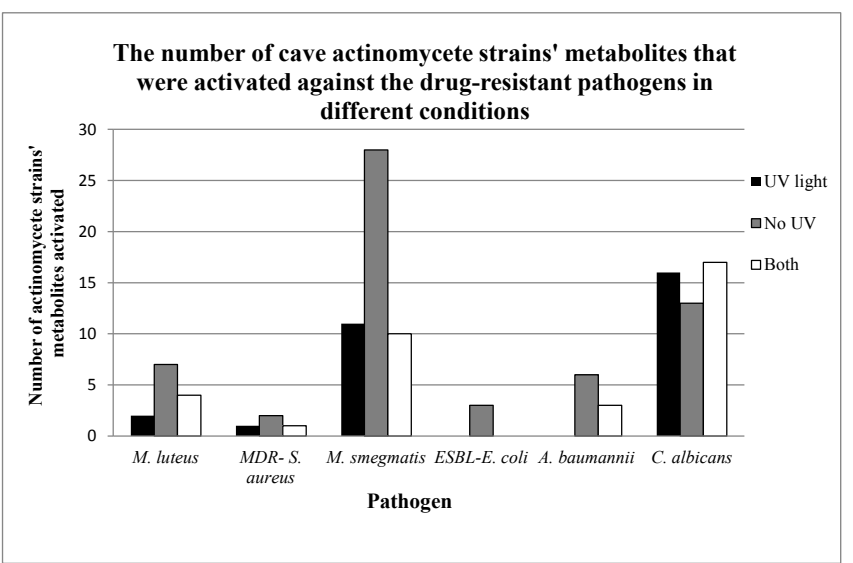

Fig. 2. The number of cave actinomycete strains' metabolites that had antimicrobial activities against the six drug-resistant pathogens in UV light, no light, and both UV light and no light conditions. 
Table 4. The antimicrobial activities of the metabolites of cave actinomycete strains E9, PM100 and E25 against the six antimicrobial-resistant pathogens used in this project. The diameters of the zones of inhibition produced by the metabolites are given in millimetres $(\mathrm{mm})$. The shaded boxes highlight the metabolites that had antimicrobial activities in UV light conditions.

\begin{tabular}{|c|c|c|c|c|c|c|}
\hline & \multicolumn{6}{|c|}{ Pathogen } \\
\hline $\begin{array}{c}\text { Actinomycete } \\
\text { strain }\end{array}$ & $\begin{array}{c}\text { M. } \\
\text { luteus }\end{array}$ & $\begin{array}{c}\text { MDR- } \\
\text { S.aureus }\end{array}$ & $\begin{array}{c}\text { M. } \\
\text { smegmatis }\end{array}$ & $\begin{array}{c}\text { ESBL } \\
\text { E. coli }\end{array}$ & $\begin{array}{c}\text { A. } \\
\text { baumannii }\end{array}$ & $\begin{array}{c}\text { C. } \\
\text { albicans }\end{array}$ \\
\hline E9 & 16 & 13 & 20 & 7 & 13 & 0 \\
\hline E9 & 12 & 9.5 & 0 & 0 & 0 & 0 \\
\hline 100 & 0 & 0 & 9 & 0 & 0 & 27 \\
\hline E25 & 12 & 13.5 & 0 & 6 & 0 & 0 \\
\hline E25 & 11 & 0 & 0 & 0 & 0 & 0 \\
\hline
\end{tabular}

\section{DISCUSSION}

Based on the results observed from the agar plug assay tested in our study, cave actinomycetes have the potential to produce antimicrobial compounds that are needed to help combat the antibiotic resistance phenomenon. In particular, the antimicrobial compounds produced by strain E9 in our study were effective against many different pathogens and may have the potential to be developed into broadspectrum antibiotics in the future. However, the chemical composition and modes of action of the antimicrobials produced in our study have yet to be determined by isolating the metabolites with highperformance liquid chromatography and examining their structures with mass spectrometry and nuclear magnetic resonance spectroscopy, as suggested by a previous study (Herold et al., 2005). The media used for antimicrobial production in the current study also need to be optimized in order to obtain the highest yield of metabolites as possible (only HT agar was

Table 5. The metabolites of six cave actinomycete strains that lost their antimicrobial activities under UV light exposure. The diameters of the zones of inhibition produced by the metabolites on the seeded plates are given in millimetres $(\mathrm{mm})$. Shaded bars represent non-UV light conditions while the white bars represent UV light conditions. The outlined boxes highlight the instances where the metabolites of the cave actinomycete strains lost their antimicrobial activities in UV light conditions.

\begin{tabular}{|c|c|c|c|c|c|c|}
\hline \multirow[b]{2}{*}{$\begin{array}{c}\text { Actinomycete } \\
\text { Strain }\end{array}$} & \multicolumn{6}{|c|}{ Pathogen } \\
\hline & $\begin{array}{c}\text { M. } \\
\text { Iuteus }\end{array}$ & $\begin{array}{c}\text { MDR- } \\
\text { S.aureus }\end{array}$ & $\begin{array}{c}\text { M. } \\
\text { smegmatis }\end{array}$ & $\begin{array}{l}\text { ESBL- } \\
\text { E.coli }\end{array}$ & $\begin{array}{c}A . \\
\text { baumannii }\end{array}$ & $\begin{array}{c}\text { C. } \\
\text { albicans }\end{array}$ \\
\hline $\begin{array}{l}\text { PM } 106 \\
\text { (DR031) }\end{array}$ & 0 & 0 & 19 & 0 & 19 & 10 \\
\hline $\begin{array}{l}\text { PM 106 } \\
\text { (DR031) }\end{array}$ & - & - & 17 & - & 17 & - \\
\hline NC-18 & 15 & 7 & 0 & 0 & 12 & 0 \\
\hline NC-18 & 12 & - & - & - & - & 0 \\
\hline NC-39 & 8 & 0 & 13 & 0 & 0 & 10 \\
\hline NC-39 & - & - & 19 & - & - & 26.5 \\
\hline E9 & 16 & 13 & 20 & 7 & 13 & 0 \\
\hline E9 & 12 & 9.5 & - & - & - & 0 \\
\hline E25 & 12 & 13.5 & 0 & 6 & 0 & 0 \\
\hline E25 & 11 & - & - & - & - & 0 \\
\hline unknown 9 & 11 & 0 & 8 & 0 & 0 & 0 \\
\hline unknown 9 & 11 & - & - & - & - & 0 \\
\hline
\end{tabular}

Table 6 . Identification of some cave actinomycetes by $16 \mathrm{~S}$ rRNA sequencing (Cheeptham et al., 2013).

\begin{tabular}{|cccc|}
\hline $\begin{array}{c}\text { Actinomycete } \\
\text { strain }\end{array}$ & $\begin{array}{c}\text { Species (Identified by 16S rRNA } \\
\text { sequencing) }\end{array}$ & \% similarity & Accession \# \\
\hline PM 106 & Streptomyces microflavus & 99 & JQ422124 \\
NC-18 & Streptomyces coelescens & 99 & JQ422176 \\
\hline NC-39 & $\begin{array}{c}\text { Streptomyces phaechromogenes } \\
\text { NRRL1248 }\end{array}$ & 99 & JQ422177 \\
E9 & Streptomyces durmitorensis & 99 & JQ422178 \\
\hline E25 & Streptomyces sp. 82293 & 99 & JQ422179 \\
SK119 & Erwinia sp. & 99 & JQ422180 \\
\hline Unknown 9 & Not sequenced & N/A & N/A \\
\hline
\end{tabular}

used). Regardless, the metabolites produced by the cave actinomycete strains in this preliminary study appear to be fairly effective antimicrobial and antifungal agents against Mycobacterium smegmatis (which is a model organism for the tuberculosis drug search) and Candida albicans in particular, and may have valuable clinical applications in the future.

The percentage of cave actinomycete strains that produced antimicrobials against the pathogens in our project is comparable to the percentage of cave Streptomyces strains that produced antimicrobials against the pathogens in another recent study (Yücel \& Yamaç, 2010). These authors tested 290 Streptomyces strains isolated from several caves in Turkey for their antimicrobial activities against MRSA, VRE, and Acinetobacter baumannii. They found that $62 \%$ or 180 out of 290 strains produced antimicrobial activities against these pathogens in the primary screening process, which is similar to the $57 \%$ or 100 out of 176 actinomycete strains that produced antimicrobial activities against the pathogens in our project.

Conversely, the percentage of cave actinomycete strains that produced antimicrobials against the pathogens in our project is high compared to a study conducted by Montano \& Henderson in 2012 to determine the effects of nutrient level and human visitation on the antimicrobial activity of cave bacteria from three carbonate caves in Carlsbad Caverns National Park, New Mexico, USA. In this study, 21.1\% of the isolates taken from the Backcountry Cave, $19.8 \%$ of the isolates taken from the Spider Cave, and $8.62 \%$ of the isolates derived from the Fort Stanton Cave showed antimicrobial activity against at least one of the five target bacterial pathogens tested against in the experiment (Staphylococcus aureus (ATCC 6538), Klebsiella pneumoniae (ATCC 13883), Proteus vulgaris (ATCC 13315), Shigella flexneri (ATCC 9199), and Streptococcus pneumoniae (ATCC 6303), compared to the $57 \%$ of cave actinomycete strains that produced antimicrobial activity against the pathogens in our project. On the other hand, a second study conducted by Montano and Henderson in 2012 to examine the effects of a lack of nutrients and cave depth on the antimicrobial activity of cave bacteria from three carbonate caves in Carlsbad Caverns National Park, New Mexico, USA, showed more comparable results to our study. In this study, $66 \%$ of the isolates in the Left Hand Tunnel passage in Carlsbad Caverns, 24\% of the isolates in Spider Cave, $24 \%$ of the isolates in Backcountry Cave, and $40 \%$ of the isolates in 
Lechuguilla Cave had antimicrobial activity against at least one of the five pathogens listed in Montano \& Henderson's first study above.

Similarly, numerous recent studies have also isolated novel Streptomyces strains from cave and desert soils that produced antimicrobial compounds against a variety of drug-resistant pathogens. For instance, earlier this year, Rajput and colleagues discovered seven novel streptomycete strains isolated from the Kotsumar Cave in India that had varying antimicrobial activities against Staphylococcus aureus MTCC 96, Escherichia coli MTCC 1667, and Pseudomonas aeruginosa JNMC (Rajput et al., 2012). Likewise, in 2005, Herold and colleagues discovered that the novel Streptomyces tendae strain HKI 0179 isolated from an ancient cave in Italy Grotta dei Cervi produced antimicrobial activities against Bacillus subtilis ATCC 6633, Staphylococcus aureus SG511, Staphylococcus aureus 134/93, vancomycin-resistant Enterococcus faecalis 1528 and efflux-resistant Staphylococcus aureus EfS4 (Herold et al., 2005). As well, in 2009, Selvameenal and colleagues showed that the novel Streptomyces hygroscopicus subsp. ossamyceticus strain D10 isolated from desert soil in Rajasthan, northwest India produced a range of antimicrobial activities against Staphylococcus aureus, vancomycin-resistant Staphylococcus aureus, extended spectrum $\beta$-lactamase (ESBL)-producing Escherichia coli and Klebsiella sp. (Selvameenal et al., 2009). Based on the results of these studies and the results of this project, the future of isolating novel antimicrobial-producing bacterial strains from lessexplored habitats such as caves is promisingly bright.

The effects of UV light on the antimicrobial activities of cave actinomycete metabolites in our study are preliminary and must continue to be investigated in the future. Previous studies have shown that some plant metabolites are able to be photoactivated against a number of pathogens with exposure to UV light (Towers et al., 1999; Cheeptham \& Towers, 2002; Hudson et al., 2002). In addition, a study carried out by Matias et al. in 2010 identified several Brazilian medical plant extracts whose antimicrobial activities against Staphylococcus aureus were enhanced when the extracts were exposed to two hours of UV light (5 $\mathrm{W} / \mathrm{m}^{2}, 320-400 \mathrm{~nm}$ from four Sylvania F20T12-BLB lamps, maximum emission at $350 \mathrm{~nm}$ - Matias et al., 2010). Similarly, in 2002, Rajakaruna and colleagues tested the antimicrobial activities of the extracts of 32 species of Sri Lankan plants against seven pathogens (MRSA, Bacillus subtilis, Enterobacter faecalis, Escherichia coli, Pseudomonas aeruginosa H187 (wild type), Mycobacterium phlei, and Candida albicans) when the extracts were subjected to 45 minutes of long wave UV light (Sylvania, F20T12/BLB, 20W, four bulbs - Rajakaruna et al., 2002). Ten extracts showed light-activated antimicrobial activities against six of the pathogens. Antimicrobial activity was enhanced with UV light exposure against Staphylococcus aureus, Bacillus subtilis, and Pseudomonas aeruginosa. However, the antimicrobial activity levels of the extracts remained the same for Enterobacter faecalis and Mycobacterium phlei when the extracts were exposed to UV light and no light conditions and no extract had light-mediated antimicrobial activities against Escherichia coli. Conversely, to our knowledge, no previous study has looked at the effects of UV light on the deactivation/activation of the antimicrobial activities of bacterial metabolites from cave actinomycetes. Photoactivation of metabolites by UV light may act as a novel source of drug discovery and more specifically, narrow spectrum antibiotics.

Future work should also examine the effects of UV light exposure on the cave actinomycete strains and pathogens that were used in this project. These microorganisms were also exposed to UV light during our project which may have had significant implications on the results obtained from our study. Short wave UV light exposure is known to cause extensive damage and mutations to arise in bacterial DNA (Snider et al., 2009). It triggers the formation of pyrimidine dimers that alter the structures of the nucleic acids and prevents DNA polymerase from replicating bacterial DNA (Farrell et al., 2009). However, some bacteria possess DNA repair mechanisms such as excision repair, post replication repair (Snider et al., 2009), SOS-repair (Chapple et al., 1992), and photoreactivation (Sayed 2011), which allow them to repair DNA damage caused by UV radiation exposure.

A study carried out by Farrell and colleagues in 2009 looked at the effects of pulsed light rich in UV-C waves (200-280 nm) on the inactivation of clinical pathogens such as Staphylococcus aureus, Enterococcus faecium, Acinetobacter baumannii, Escherichia coli and Pseudomonas aeruginosa (Farrell et al., 2009). One pulse per second of pulsed light was administered and the amount of light pulses given varied from 0 to 60 . The distance of the light source from the pathogens ranged from $8-20 \mathrm{~cm}$. Overall, the levels of each of the pathogens were reduced by approximately $7 \log _{10}$ CFU cm$~^{-2}$ with exposure to the pulsed light. Greater inactivation occurred as the intensity of the light source and the number of pulses increased, and as the distance of the pathogen plates from the light source decreased. Thus, it is possible that the levels of the pathogens used in our project may have decreased with UV light exposure as described by these studies. Future aspects for our next study should explore this possibility, along with the effects of different UV exposure times on the pathogens used in the current study, as all plates were previously exposed to one hour of UV light.

Similarly, the response of cave bacteria to UV light was previously measured in a study conducted by Northup et al. (2004). In this study, bacterial cultures from Four Windows Cave, a lava tube in New Mexico, USA, were tested for their sensitivity to a 100 and 50 second dosage of UV light. All of the strains tested showed varying sensitivity to the 100 second dose of UV light, while all but four strains were sensitive to the 50 second dose of UV light. The bacterial strains taken from inside the cave were also more sensitive to UV light than the bacterial strains taken from the 
surface of the cave. These results suggest that cave bacteria lose their resistance to UV light as part of an evolutionary adaptation to living in a dark environment. Accordingly, Snider et al. (2009) conducted a study demonstrating that bacteria from Left Hand Tunnel in Carlsbad Caverns, New Mexico, USA had a reduced ability to survive damage caused by UV light exposure. However, actinomycetes from the Left Hand Tunnel of the Carlsbad Caverns experience a great deal of human interaction, making these bacteria less like true cave-adapted strains. Regardless, it is possible that exposing cave microorganisms that traditionally live in the dark to new, lighted environments may stimulate the antimicrobial activities of their metabolites without having any serious consequences on their cells. However, given the results of these studies, future work must examine the effects of UV light on the cave actinomycetes used in our study.

It is possible that this study may also be improved by slightly modifying the way that the plug assay is carried out. For example, shortening the UV exposure time and exposing the cave actinomycete HT agar plates to UV light before taking plugs of the strains may prevent the pathogens from being exposed to UV light and from potentially influencing the results of the assay. Additionally, culturing each of the cave actinomycete isolates in fermentation broth, transferring the metabolites in the broth onto sterile paper disks, and exposing these impregnated paper disks separately to UV may help us better understand the effects of UV exposure on the metabolites. Overall, however, our study serves as an important pilot study for future work regarding the effects of UV light on the antimicrobial activities of cave actinomycete metabolites. It is vital that future studies continue to search for novel antimicrobial-producing actinomycete strains in less-explored habitats like caves and continue to test the effects of UV light on the antimicrobial activities of cave actinomycete metabolites in order to help combat the ever-increasing phenomenon of antimicrobial resistance.

\section{ACKNOWLEDGEMENTS}

Enormous thanks goes out to all who made this project possible, including: the TRU Research Enhancement Fund and the Comprehensive Undergraduate Enhancement Research Fund (CUEF) for funding the project, at TRU Carolynne Fardy, Carley MacIntyre, Shannon Brooks, and Paul Moote for lab assistance, Dr. Ken Wagner for his assistance in regards to clinical microbiology, Kent Watson for cave mapping assistance and Dr. Nancy Flood for assistance with statistics. Our gratitude goes to Drs. Julian Davies of UBC and Gwen Stephens of RIH for donating the bacterial pathogens used in this project and the Ministry of Forests and Lands and Natural Resource Operations for Park Use Permit \#102172.

\section{REFERENCES}

Chapple R.M., Inglis B. \& Stewart P.R., 1992 - Lethal and mutational effects of solar and $U V$ radiation on Staphylococcus aureus. Archives of Microbiology, 157: 242-248.

http://dx.doi.org/10.1007/BF00245157

Cheeptham N. \& Towers G.H.N., 2002 - Light-mediated activities of some Thai medicinal plant teas. Fitoterapia, 73: 651-662. http://dx.doi.org/10.1016/S0367-326X(02)00224-1

Cheeptham N., Sadoway T., Rule D., Watson K., Moote P., Soliman L.C., Azad N., Donkor K. \& Horne D., 2013 - Cure from the cave: volcanic cave actinomycetes and their potential in drug discovery. International Journal of Speleology, 42: 35-47. http://dx.doi.org/10.5038/1827-806X.42.1.5

Davies J. \& Davies D., 2010 - Origins and evolution of antibiotic resistance. Microbiology and Molecular Biology Reviews, 74: 417-433.

http://dx.doi.org/10.1128/MMBR.00016-10

Farrell H.P., Garvey M., Cormican, M., Laffey J.G. \& Rowan N.J., 2009 - Investigation of critical interrelated factors affecting the efficacy of pulsed light for inactivating clinically relevant bacterial pathogens. Journal of Applied Microbiology, 108: 1494-1508. http://dx.doi.org/10.1111/j.1365-2672.2009.04545.x Genilloud O., González I., Salazar O., Martín J., Tormo J. \& Vicente F., 2011 - Current approaches to exploit actinomycetes as a source of novel natural products. Journal of Industrial Microbiology \& Biotechnology, 38: 375-398. http://dx.doi.org/10.1007/s10295-010-0882-7

Groth I., Vetermann R., Schuetze B., Schumann P. \& Saiz-Jimenez C., 1999 - Actinomycetes in karstic caves of Northern Spain (Altamira and Tito Bustillo). Journal of Microbiological Methods, 36: 115-122. http://dx.doi.org/10.1016/S0167-7012(99)00016-0

Groth I., Schumann P., Laiz L., Sanchez-Moral S., Cañaveras J.C. \& Saiz-Jimenez C., 2001 Geomicrobiological study of the Grotta dei Cervi, Porto Badisco, Italy. Geomicrobiology Journal, 18: 241-258. http://dx.doi.org/10.1080/01490450152467778

Herold K., Gollmick F.A., Groth I., Roth M., Menzel K.D., Mollmänn U., Gräfe U. \& Hertweck C., 2005 Cervimycin A-D: A polyketide glycoside complex from a cave bacterium can defeat vancomycin resistance. Chemistry - A European Journal, 11: 5523-5530. http://dx.doi.org/10.1002/chem.200500320

Hudson J.B., Anani K., Lee M.X., De Souzâ C., Arnason J.T. \& Gbeassor M., 2000 - Further investigations on the antiviral activities of medicinal plants of Togo. Pharmaceutical Biology, 38: 46-50. http://dx.doi.org/10.1076/1388-0209(200001)3811BFT046

Matias E.F.F., Santos K.K.A., Costa J.G.M. \& Coutinho H.D.M., 2010 - Light-enhanced antibiotic activity of Brazilian medical plants (Croton campestris A, Ocimum gratissimum $L$ and Cordia verbenaceae $D C$ ). Asian Biomedicine, 4: 183-186.

Montano E. T. \& Henderson L.O., 2012 - Studies of Antibiotic Production by Cave Bacteria. In: Cheeptham N. (Ed), Cave Microbiomes: A Novel resource for Drug Discovery". Springer Briefs in Microbiology. Springer: 109-130.

Murakami T., Anzai H., Imai S., Satoh A., Nagaoka K. \& Thompson C.J., 1986 - The bialaphos biosynthetic genes of Streptomyces hygroscopicus: Molecular cloning and characterization of the gene cluster. Molecular and General Genetics, 205: 42-53.

http://dx.doi.org/10.1007/BF02428031 
Northup D.E., Connolly C.A., Trent A., Peck V.M., Spilde M.N., Welbourn W.C. \& Natvig D.O., 2004 - The nature of bacterial communities in Four Windows Cave, El Malpais National Monument, New Mexico, USA. AMCS Bulletin 19 / SMES Boletín, 119-125.

Rajakaruna N., Harris C.S. \& Towers G.H.N., 2002 Antimicrobial activity of plants collected from serpentine outcrops in Sri Lanka. Pharmaceutical Biology, 40: 235-244. http://dx.doi.org/10.1076/phbi.40.3.235.5825

Rajput Y., Biswas J. \& Rai V., 2012 - Potentiality test in antimicrobial activity and antibiotic sensitivity of subterranean Streptomyces strains isolated from Kotumsar Cave of India. International Journal of Biological Chemistry, 6: 1-8.

Sayed W.F., 2011 - Preliminary evidence on photoreactivation of Frankia spores with visible light after exposure to $U V-C$ radiation. Acta Microbiologica et Immunologica Hungarica, 58: 93-103.

http://dx.doi.org/10.1556/AMicr.58.2011.2.2
Selvameenal L., Radhakrishnan M. \& Balagurunathan R., 2009 - Antibiotic pigment from desert soil actinomycetes; biological activity, purification and chemical screening. Indian Journal of Pharmaceutical Sciences, 71: 499-504

http://dx.doi.org/10.4103/0250-474X.58174

Snider J.R., Goin C., Miller R.V., Boston P.J. \& Northup D.E., 2009 - Ultraviolet radiation sensitivity in cave bacteria: evidence of adaptation to the subsurface? International Journal of Speleology, 38:11-22. http:/ /dx.doi.org/ 10.5038/1827-806X.38.1.2

Towers G.H.N, Page J. \& Hudson J. B., 1997 - New aspects of light-mediated activities of natural products from plants and fungi. Current Organic Chemistry, 1: 395-414.

Yücel S. \& Yamaç M., 2010 - Selection of Streptomyces isolates from Turkish karstic caves against antibiotic resistant microorganisms. Pakistan Journal of Pharmaceutical Sciences, 23: 1-6. 